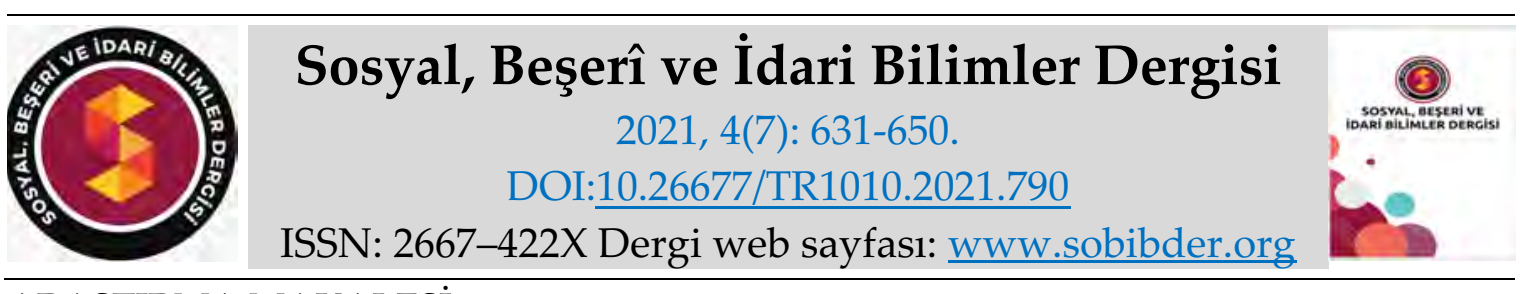

ARASTIRMA MAKALESI

\title{
Siyasal Katılımda Sosyal Ağların Rolü: Üniversite Öğrencileri Üzerine Bir Araştırma*
}

Meral ÇENGEL, Yüksek Lisans Öğrencisi, Burdur Mehmet Akif Ersoy Üniversitesi, Sosyal Bilimler Enstitüsü, Burdur, e-posta: meralcengel03@outlook.com

ORCID: https://orcid.org/0000-0003-3439-133X

Doç. Dr. Ümmühan KAYGISIZ, Burdur Mehmet Akif Ersoy Üniversitesi, İ̈BF, Burdur, e-posta: ukaygisiz@mehmetakif.edu.tr

ORCID: https://orcid.org/0000-0003-0418-0144

$\ddot{O} z$

Siyasal katılım, siyasal alanlarda yapılan faaliyetler ile vatandaşların farklı şekillerde yönetimi elinde bulunduran veya siyasal manada iktidarda bulunan kesim üzerinde baskı kurmaları, doğrudan veya dolaylı bir şekilde siyasal sürece katılarak çeşitli etkiler oluşturma faaliyetleridir. Geleneksel katılım metotları kadar teknolojinin gelişmesi ile yaşanan toplumsal dönüşümler ve inovatif gelişmelerle birlikte modern katılım türleri de önem kazanmıştır. Çalışmanın amacı teknolojik gelişmeler ile günlük hayatta yer alan sosyal ağların bu ağları en çok kullanan öğrencilerin siyasal katılımları üzerine etki edip etmediğini analiz etmektir. Bu nedenle Burdur Mehmet Akif Ersoy Üniversitesi İktisadi ve İdari Bilimler Fakültesi'nde öğrenim gören öğrenciler üzerinde siyasal katılım davranışları ile sosyal ağların etkisi incelenmiştir. Sonuç olarak sosyal ağların üniversite öğrencileri tarafından sıkça kullanıldığı, bu kullanımların öğrencilerin siyasete ilgilerini artırdığı ancak genel olarak öğrencilerin aktif siyasal katılım davranışlarında sosyal ağların etkili olmadığı sonucu elde edilmiştir.

* Bu makale, adıyla aynı olan tezden türetilmiştir.

Anahtar Kelimeler: Siyasal Katılım, Sosyal A ̆g, Siyasal Davranış.

Makale Gönderme Tarihi: 26.03.2021

Makale Kabul Tarihi: 02.07.2021

\section{Önerilen Atıf:}

Çengel, M. ve Kaygısız, Ü. (2021). Siyasal Katılımda Sosyal Ağların Rolü: Üniversite Öğrencileri Üzerine Bir Araştırma, Sosyal, Beşeri ve İdari Bilimler Dergisi, 4(7): 631-650.

(C) 2021 Sosyal, Beşerî ve İdari Bilimler Dergisi. 


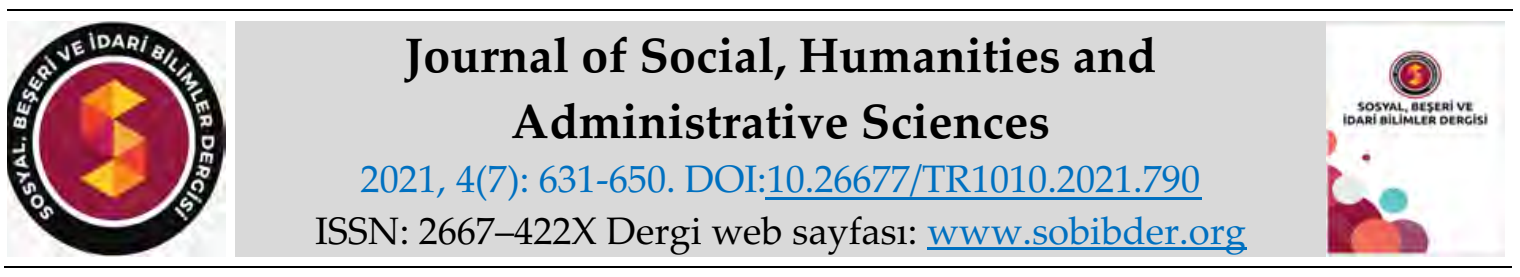

RESEARCH PAPER

\title{
The Role of Social Networks in Political Participation: A Research on University Students
}

Meral ÇENGEL, MSc. Student, Burdur Mehmet Akif Ersoy University, Social Sciences Institute, Burdur, e-mail: meralcengel03@outlook.com

ORCID: https://orcid.org/0000-0003-3439-133X

Associate Prof. Dr. Ümmühan KAYGISIZ, Burdur Mehmet Akif Ersoy University, Faculty of Economics and Administrative Sciences, Burdur, e-mail: ukaygisiz@mehmetakif.edu.tr

ORCID: https://orcid.org/0000-0003-0418-0144

\begin{abstract}
Political participation is the activities that are carried out in the political fields and the pressure of the citizens on the part that holds the government in different ways or who is in power in the political sense, to create various effects by directly or indirectly participating in the political process. Along with traditional participation methods, social transformations experienced with technology development and modern participation types gained importance along with innovative developments. The aim of the study is whether the technological developments and social networks in daily life affect the political participation of the students who use these networks the most. For this reason, the political participation behaviors and the effect of social networks on the student studying in Burdur Mehmet Akif Ersoy University Faculty of Economics and Administrative Sciences were examined. In the study; social networks are frequently used by university students, these uses increase students' interest in politics however, it was concluded that social networks were not effective in the active political participation behaviors of students in general.
\end{abstract}

Keywords: Political Participation, Social Networking, Political Behaviour.

Received: 26.03 .2021

Accepted: 02.07.2021

\section{Suggested Citation:}

Çengel, M. and Kaygisız, Ü. (2021). The Role of Social Networks in Political Participation: A Research on University Students, Journal of Social, Humanities and Administrative Sciences, 4(7): 631650.

(c) 2021 Sosyal, Beşerî ve İdari Bilimler Dergisi. 


\section{Gíriş}

Siyasal katılım geniş anlamda hem yerelde hem de genelde oluşturulan siyasal alanlarda yapılan faaliyetler ile vatandaşların farklı şekillerde yönetimi elinde bulunduran veya siyasal manada iktidarda bulunan yönetsel kararları etkileme ve doğrudan ya da dolaylı bir şekilde siyasal sürece katılarak çeşitli etkiler oluşturmaları faaliyetleridir.

Siyasal katılım davranışları çok çeşitli olmasına rağmen, bilgi iletişim teknolojilerindeki gelişim toplumlardaki her tür davranış modülünü değiştirdiği gibi siyasal katılım davranışlarını da etki ederek değiştirmektedir. Her geçen gün daha hızlı gelişen teknolojik gelişmelerin ve dijitalleşmenin ortaya çıkardığı en önemli siyasal katılım aracı farklı çeşitlilikteki sosyal ağlardır. M.Ö. 3000 yılında Mısırda Hiyeroglif adı verilen insan ve hayvan şekillerini sembol olarak işleyen bir sistemden başlayıp günümüze kadar dönüşerek gelen iletişim sistemleri, her geçen gün farklı kullanım alanları ortaya çıkarmaktadır. Sosyal ağlar, toplum tabanlı, etkileşim, içerik paylaşımı ve işbirliği amaçlı kanallarının bütünü olarak kabul edilen her türlü araç, sistem ve yazılımlardır. Sosyal ağlar genel olarak günlük yaşantıda kullanılan youtube, instagram, twitter, facebook gibi ağlarla insanların resim, yazı paylaştıkları bir takım sosyalleşme ve eğlence platformlarıdır. Günümüzde böylesine önem arz eden sosyal ağlar ile siyasal katılım arasında bir ilişki olup olmadığına yönelik çeşitli araştırmalar yapılmış ve yazılar yazılmıştır.

Çalışmanın amacı kişilerin günlük hayatta her zaman kullandığı sosyal ağların, kişilerin siyasal katılımını ne şekilde etkilediğini ortaya koymaktır. Bu doğrultuda ilk olarak siyasal katılım ve sosyal ağ kavramları açıklanıp aralarındaki ilişki ortaya konulmuştur. Araştırma kısmında ise, Mehmet Akif Ersoy Üniversitesi İktisadi ve İdari Bilimler Fakültesi öğrencilerinin katılımıyla yapılan alan araştırması, veri analiz programı ile analiz edilmiş, bulgular ortaya konulmuştur.

\section{SIYYASAL KATILIM}

Katılım, düşünce ya da çalışmalar aşamasında olan eylem veya fikre katılmak veya mevcut olan durumu ve görüşü paylaşmaktır (Kaypak, 2010: 136). Bunun yanı sıra katılım genel olarak kişinin yaşadığı çevrede meydana gelen veya gelmesi mümkün olan olaylar karşısında karar alma sürecidir (Kabaoğlu, 2013: 240). Katılım kavramının çeşitli tanımlarının olmasından dolayı siyasal katılım kavramının da çeşitli tanımları vardır. Siyasal katılım, bir toplumsal çevrede bireylerin yerel ve uluslararası siyasal seviyede yöneticileri seçme ve yöneticilerin, bireyin kendi istek ve çıkarları doğrultusunda karar almalarını sağlamak için gösterdikleri her türlü davranış ve eylemlerdir (Dursun, 2012: 234).

Bu kapsamda bireylerin, devletin kararlarını, eylemlerini etkileyen yasalar, yasa dışı hareketler, şiddete ve bir işe dayall, başarıya ulaşamamış veya ulaşmış her türlü hareket ve davranışlarının etkilemesine yarayan bütün işlemlere siyasal katılım denilmektedir (Dursun, 2012: 235).

Vatandaşların siyasal düzen karşısında durumları, tutumları ve davranışlarına karar veren eylem aracı ise siyasal katılımdır (Fedayi, 2002: 172). Diğer bir deyişle bu katılım basit bir merakla başlayıp derin eyleme doğru uzanan bir süreçtir. Örneğin siyasal konularla ilgili gazete okumak basit bir merak iken siyasal bir mitinge katılmak ve siyasi bir liderle görüşmek ise derin bir eylemdir.

Siyasal katılım en geniş anlamıyla; bir bölge ya da ülkede toplumu oluşturan bireylerin siyasal sistem ile kendi aralarında kurmak istediği veya kurduğu bütün ilişki biçimlerini kapsamaktadır (Gökçimen, 2008: 8). Bu ilişki siyasal bir konu hakkında bilgi alma, takip etme, bilgi toplama, oy verme, siyasal olaya destek ya da tepki verme, seçimlerde aday olma, seçilmiş yöneticilerin almak istedikleri kararlarına katılma gibi eylemleri içermektedir. 
Kişilerin veya kurumların siyasal katılım düzeylerini açıklamaya yönelik olarak akademik çevreler ve araştırmacılar çok çeşitli araştırmalar yapmışlardır. Ancak genel olarak kabul görenler M. E. Olsen ve Milbrath'ın ortaya koyduğu katılım düzeyleridir.

M.E. Olsen siyasal katılım düzeyini toplumların davranışlarını inceleyerek açıklamıştır. Olsen'a göre toplumun siyasal katılım düzeyi bakımından toplum alt gruplara ayrılmaktadır. Bu gruplar genel olarak şu şekildedir; (Olsen, 1970: 681-683 veya Aydın, 2017: 52)

a) Siyasal vatandaşlar; bir ülkede seçimlere katılıp oy kullanan, siyasal olaylar hakkında bilgi sahibi olmak için faaliyet yapan ancak siyasal alanda aktif olarak yer alamayan kişilerin oluşturduğu grup.

b) Siyasal iletim; bu gruptaki kişiler ise siyaseti takip edip öğrendikleri bilgileri başkasına aktaran ve bunları dinleyen kişilerden oluşur.

c) Siyasal aktivistler; bu grup ise siyasi bir partiye üye olan ve o parti için aktif bir şekilde çalışan kişilerden oluşur.

d) Liderler; ülkede devlet yönetimine seçilerek veya atanarak gelen kişilerin oluşturduğu grup.

e) Siyasal dışlanmışlar; siyasal yaşamda ortaya çıkan olaylara hiçbir şekilde karışmayan kişilerdir.

f) Siyasal marjinaller; siyasal olaylar karşısında sosyal ağlar aracılığıyla az da olsa bilgi sahibi olan ve bunlar üzerinde konuşan kişilerdir.

Milbrath ise siyasal katılım düzeyini toplumu inceleyerek ortaya koymuştur. Milbrath'a göre siyasal katılım düzeyleri şunlardır; (Milbrath, 1965: 11-15 veya Aydın, 2017:54)

a) Açıklayıcı katılım; siyasal yaşamda sembol haline gelen aygıtları kullanma, siyasetle ilgili yapılan toplantılara katılma, kendi görüşünde olan veya olmayan insanlarla tartışma gibi özelliklerin yer aldığı sınıftır. Diğer yandan araçsal katılım ise bireylerin kişisel olarak değil de belirli bir araçlarla siyasal katılım gerçekleştirmesidir.

b) Açık ve gizli katılım sınıfı; bireylerin kendi psikolojik yapıları nedeniyle siyasal katılımlarını açık veya gizli bir şekilde yapması.

c) Sürekli ve anlık katılım sınıfı; bireyin anlık olarak siyasal olay ve eylemlere katılırken, kimi zaman da siyasal alanda sürekli olarak yer almasını sağlayan eylemleri içeren faaliyetlere katılması.

d) Zorunlu ve bağımsız katılım sınıfı; devletin belirli eylemlere karşı belirli kanunlar aracılı̆̆ı ile bireyin zorunlu katılımı sağlanırken, diğer yandan bireyler bazı alanlarda devletin zorunluluğundan bağımsız olarak katılım gerçekleştirmektedir.

e) Bireylerin katılımlar karşılığında belli hizmet ve siyasal yönetim kesimi tarafından ödüllendirilmesini içeren siyasal sisteme veren ve sistemden alan katılım sınıfıdır.

d) Toplumsal olan ve toplumsal olmayan katılım sınıfı; bireylerin tek başına katıldığı oy vermek gibi toplumsal olmayan ve bireylerin birlikte gerçekleştirdiği toplumsal katılım faaliyetleri.

e) Bireylerin sözlü veya sözsüz bir şekilde katılımını içeren tür ise sözlü ve sözsüz katılımdır.

Siyasal katılım araçları ise:

a) Seçimler: Devlet yapısının olmazsa olmazı olarak kabul edilenlerin arasında yer alan seçimler, genel olarak halkın kendisi yerine belirli bir süre için devletin yönetim kesiminde bulunan kişi veya kişilerin seçilme işlemidir (Göksu ve Bilgiç, 2003:54). Bu tanımdan da anlaşılacağı üzere seçimin iki temel özelliği vardır. Birincisi halkın, kendisi için yapılacak hizmetlerle ilgili alınacak 
kararları ve sonuçları ayrı ayrı oylamasıdır. İkincisi ise alınacak kararlara ve sonuçlara kendisini temsil etmesi için uygun kişiyi seçmesidir.

b) Halk Denetimi: Halkın kendisini temsil etmesi için seçilen kişilerin görevlerini hakkı ile yerine getirip getirmediğinin denetlenmesidir. Halk denetimi, halkın baskı gruplarını kullanarak, bir araya gelip, birlikte hareket etmesi sonucu seçilmiş kişi veya kişilerin denetlenmesini içen yapıdır (Sağır, 2003: 33).

c) Halk Toplantısı: Gelişmiş, gelişmekte olan ve gelişmemiş toplumlarda bazı kesimler yönetime rahat bir şekilde ulaşıp etkileyebilirken, bazı kesimlerin ise bu imkânı yoktur. İşte halk toplantısı dezavantajlı grubun siyasal katılımını sağlamak amacıyla ortaya çıkmıştır (Çevikbaş, 2008: 81). Kısaca halk toplantısı, devletin kurum ve kuruluşlarında yönetici olarak bulunan kişilere, onlara ulaşamayan kişilerin aralarındaki mesafeyi kapatmak için planlı ve kendiliğinden gelişen toplantılardır.

d) Halk Girişimi: Halk girişimi genel olarak halkın kendi isteği ile herhangi bir konuda, yeni çıkmış veya daha önceden bulunan yasayla ilgili olarak ortaya koyduğunu yapma ve değiştirme imkânı olmasıdır (Karagöz, 2010: 81). Bu tanım çerçevesinde halk girişimi devlet yönetiminde bulunan kişilerin değil de halkın kendi iradesiyle bir yasa hazırlayarak kamuoyu gündemine getirmesidir.

e) Halk Vetosu: Seçilmiş yöneticilerin ani bir şekilde karar almasını engellemek amacıyla geliştirilmiş ve halkın yönetime doğrudan katılmasını sağlayan hukuki ve siyasi bir sistemdir (Gözler, 2004: 122). Geliştirilen bu sistem ile devletin karar alma organı tarafından düzenlenip, kabul edilen kanun ve politikaların halka sunularak, halkın belirli bir süre içinde kanun ve politikayı kabul veya reddetme olanağı sağlayan yöntemdir.

f) Referandum: Bir konu hakkında halkın görüşünü almaya yönelik yapılan oylamadır (Gözler, 2014: 94). Bu tanımdan da anlaşılacağı üzere devletin karar alma organları tarafından hazırlanan bir konuda halkın görüşünü almak için yapılan oylama işlemidir.

g) Halkla İlişkiler: Devlet yönetimi açısından, devletle halkın karşılıklı yarar sağlaması için kurulan bir iletişim biçimidir. Diğer yandan ise halk açısından, kendisini temsil etmesi için seçtiği kişilere, kendisi için daha çabuk ulaşmasını sağlayan geri bildirimli bir iletişim sistemi olarak da tanımlanabilir (Kurt, 2001: 21-22).

\section{SOSYAL A $\breve{G}$}

Sosyal ağlar, toplum tabanlı, etkileşim, içerik paylaşımı ve işbirliği amaçlı kurulan kanalların bütünüdür (Alper, 2012: 21). Başka bir deyişle sosyal ağ, çevrimiçi network sitelerinin, blokların tüm dünyayı etkileyecek şekilde, çok hızlı ve anlık olarak iletişim sağlaması yoluyla kişilerin bilgi, görüş ve haberlere hızlı ulaşmasını sağlayan ağ sistemidir (Tosun, 2018: 5). Sosyal ağ, iletişim ağının ürettiği şeylerin tümünü ya da herhangi birini, herhangi bir yerden paylaşılması ve üretilmesi için tasarlanan teknolojik bir üründür.

Sosyal ağ kavramının ilk bölümü olan "sosyal" kelimesi, insanların sosyal bir varlık olması nedeniyle başkaları ile iletişim kurmak zorunda olduğunu ifade etmektedir. Yani bir insanın kendisi gibi düşünen, yaşayan insanlar ile o insanların sanki yanlarında ya da evlerinde gibi rahat hissedebileceği, fikirlerini, hissettiklerini, hayatta elde ettikleri tecrübelerini paylaşabilecekleri bir gruba dahil olmasıdır. Sosyal ağ kavramının ikinci kısmını oluşturan "ağ" kavramı ise sosyal olan bu insanların iletişime geçmek için kullandıkları yöntemlerin tümüdür. Bu iletişim tarih boyunca farklı yöntemlerle ortaya çıkmıştır. Davullar, çanlar, yazılar, mektuplar, telefonlar, radyolar, televizyonlar, web siteleri, fotoğraflar gibi iletişimi sağlayan her türlü araçlar ağların 
parçasıdır (Aslan, 2011: 3-9). Yani sosyal olan insanın iletişimini sağlamak için kullanılan teknolojilerin tümüdür. Başlıca sosyal ağ türleri şöyledir:

A $\breve{g}$ Siteleri: Bu siteler genel olarak kurma sistemi ile kişilerin fotoğraf paylaşması, profil oluşturması, kendi veya başkalarının bilgilerini görmesine olanak sağlayan web tabanlı sistemlerdir (Ayan, 2016: 302). A $\breve{g}$ sitelerinden en yaygın olanları Myspace, Linkedin ve Facebook'tur. Myspace, genel olarak kişilerin oluşturdukları video, yazı ve resimlerin paylaşıldığı bir ağ sitesidir (Metin, 2010: 225). İş dünyasındaki kişilerin daha hızlı ve rahat iletişim kurarak daha verimli olmasını sağlamak için kurulan ağ sitesi ise Linkedin'dir (Metin, 2010: 227). A $\breve{g}$ sitelerinden en yaygın olanı ise bireylerin başka bireyler ile iletişim kurmasını sağlayan Facebook'tur.

Bloglar: Kişisel hayat içerisinde kişilerin günlük olarak düşüncelerini, gözlemlerini yazdıkları ve başka kişilerin bunlara yorum yazdığı web tabanlı web günlükleridir (Eldeniz, 2010: 3).

Mikrobloglar: Bloglardan farklı olarak sınırlı karakteri olan ve kişilerin anlık düşüncelerini paylaşıp, başka kişilerin anlık mesajlarının takip edildiği ağ siteleridir. Bu mikrobloglardan en yaygın olanı 2006 yılında Jack Dorsey tarafından kişilerin düşüncelerini anlık olarak paylaştırması için kurulan twitterdır (Korkmaz, 2014: 19).

İçerik Paylaşım Siteleri: Özel bir konu hakkında bir araya getirilmiş materyallerin paylaşıldığı yerdir. Genel olarak video içerik paylaşım sitesi ve resim içerik paylaşım sitesi olarak ikiye ayrılmaktadır. Video içerik paylaşım sitesi, kişilerin herhangi bir konu hakkında video çekim paylaştıkları yerdir. Bunlardan en yaygın olanı Jawed Karim tarafından 2005 yılında kurulan youtubedir. İkincisi ise kişilerin hayatlarında önemsediği anlak şeylerin yıllarca kalmasını sağmak ve başkalarında görmesi için çektikleri resimleri paylaştıkları resim içerek paylaşım sitesidir. En yaygın olanı ise Kevin Systrom ve Mike Krieger tarafından 2010 yılında kurulan instagramdır (Karaman, Yıldırım ve Kaban, 2018: 36).

Wiki ve Formlar: Kişilerin gönüllülük esasına göre bilgi sahibi olduğu herhangi bir konuda bilgi verdiği wiki isimli sitelerdir. Formlar ise wikiden farklı olarak özel bir konu üzerine tartı̧mak için kurulan sitelerdir (İşlek, 2012: 42-43).

\section{SIYYASAL KATILIM DAVRANIŞLARINDA SOSYAL AĞLARIN ETKİSI}

Katılımcllık konusu, siyaset ve demokrasi açısından her zaman önemli olmuştur. Çünkü güçlü bir demokrasi katılımcı demokrasinin modern şeklidir. Bu demokrasi anlayışında vatandaşlar, ortak davranış ve katılımcı kurumlar sayesinde ortak amaç ve karşılıklı eylemde bulunabilme fikrine sahiptir (Barber, 2003: 117). Demokrasi ve siyaset için önemli olan siyasal katılımın vatandaşlar tarafından, iyi anlaşılıp, yaygın şekilde gerçekleştirilmesidir. Siyasal katılımın her alanda kullanılmasına yarayan araçlardan en önemlisi günümüzde sosyal ağlardır. Siyaset, demokrasi ve sosyal ağlar arasındaki ilişki üzerine geçmişten günümüze hem yurt içi hem de yurt dışı çeşitli çalışmalar yapılmıştır ve yapılmaya devam etmektedir.

Siyasal katılımda sosyal ağlardan olan kitle iletişim araçlarının seçmenleri etkiyip etkilemediğini öğrenmek için çeşitli çalışmalar yapılmıştır. Bu çalışmalar sonucunda kitle iletişim araçlarının siyasal katılımı doğrudan etkilediği bulunmuştur. Buna göre siyasal iktidarı elde etmek isteyen veya elinde tutmak düşüncesine sahip siyasi partiler sosyal ağları, seçmenleri etkilemek ve seçmenlerin düşüncelerini değiştirerek iktidara gelmek için kullanmaktadırlar (Dilber, 2012: 155190).

Sosyal ağları kullanmak için olması gereken sistemden biri olan internet kullanımının sosyal ağlara ve siyasal katılıma etkisi üzerine öğrenciler baz alınarak çalışmalar yapılmıştır. Bu 
çalışmalar sonucunda öğrencilerin internet aracılıyla sosyal ağları etkili bir şekilde kullandıkları görülmüştür. Bu kullanımların öğrencilerin siyasete ilgilerini artırarak siyasal katılımın gelişmesine ve artmasına yol açtığı görülmüştür (Eser, 2015: 197-219).

Bunlardan başka öğrencilerin siyasal katılımında sosyal ağların etkisinin ne olduğu üzerine de çalışmalar yapılmıştır. Bu çalışmalar sonucunda öğrencilerin sosyal ağları aktif olarak kullandıkları görülmüştür. Bu kullanıma bakıldığında öğrencilerin siyasal bilgi edinmek için facebook ve twitterı tercih ettikleri, siyasal bilgilendirme amaçlı ise instagramı kullandıkları görülmüş̧ür. Kısaca sosyal ağ kullanımı siyasal katılımı olumlu olarak etkilemektedir (Görgülü, 2018: 65-108).

Siyasal iletişim ile sosyal ağ arasındaki ilişkiden yola çıkarak siyasal katılımda sosyal ağların etkisi üzerine Wolton tarafından yapılan çalışmada; ikna, işbirliği ve uzlaşma, siyasal iletişimin unsurları olarak tespit edilmiştir. Bu üç unsuru bir araya getirmeyi başaran partiler, rakiplerine karşı üstün duruma geçerek iktidara daha çabuk ulaşırlar. Siyasal iletişim aracı olarak sosyal ağlar, siyasette ilk zamanlarda siyasetçilerin halkı etkilemek için kullandıkları bir araç iken, zamanla gelişmesi sonucu siyasetçiler ve partiler için halkın siyasete katılmasını sağlayarak, oy oranlarını arttırmak, bu sayede iktidara daha hızlı ulaşmak amacına hizmet eden bir araç haline gelmiştir (Wolton, 1991: 43).

Francis Fukuyama'ya göre ise siyasal katılımı artıran en önemli unsur sosyal ağlardır. O'na göre, sosyal ağlar siyasal anlamda haber alma özelliği taşıyan araçlar ile birey ve kamu arasında iletişim sağlayan araçlardır. Bu nedenle sosyal ağlar iktidardaki kişilerin aldıkları kararları halka iletirken, halkın istek ve şikâyetlerini iktidara ulaştırır. Kısaca siyasal katılımın sosyal ağların hepsiyle doğrudan bir ilişkisi vardır (Fukuyama, 2010: 137-163).

Sosyal ağ ile siyasal katılım arasındaki ilişkiyi direkt ortaya koymak için M. Marko Skoric tarafından yapılan çalışma sonucunda elde edilen en önemli bilgi ise, geleneksel sosyal ağ kullanımın, yeni sosyal ağlardan daha fazla siyasal katılımı etkilediğidir. Geleneksel sosyal ağlardan olan telgrafın zamanla gelişerek yeni sosyal ağ olarak kabul edilen e mail, eposta haline gelmesi bu durum için geçerlidir. Çünkü yeni sosyal ağlarda bireyler başka alanlara kayabilirken, geleneksel ağlarda böyle bir imkân daha azdır (Skoric ve Poor, 2013: 187).

\section{ARAŞTIRMANIN AMACI, KAPSAMI, YÖNTEMI}

Çalışma, Burdur il merkezinde bulunan Mehmet Akif Ersoy Üniversitesi'nin lisans eğitimi veren İktisadi ve İdari Bilimler Fakültesi'nde yapılmıştır. Çalışmanın temel amacı sosyal ağları etkili ve yaygın olarak kullanan üniversite öğrencilerinin siyasete bakışları ile sosyal ağların siyasal katılımlarına etkisini ortaya koymaktır. Çalışmanın evren büyüklüğü 3.269 kişidir. Evreni oluşturan katılımcılardan 1893 kişi kadın, 1376 kişi erkektir. Basit tesadüfi örnekleme yöntemi (Türkdoğan, 2000: 78) ile evren dikkate alınarak pilot çalışma için 200 kişi, 400 kişi anketin ana araştırması için olmak üzere toplam 600 katılımcıya ulaşılmıştır. Anketler yüz yüze yapılmıştır.

Araştırmanın ölçek kısmına gelindiğinde, ölçeği oluşturmada hem yurt içinde hem de yurt dışındaki yapılan araştırmalar incelenmiş ve konuyla ilgili uygun olan ölçekler gözden geçirilerek 7 tane demografik ve 33 tane siyasal ve sosyal ağ davranışlarına ilişkin anket soruları oluşturulmuştur. Araştırmanın demografik sorularının oluşturulmasında Görgülü (Görgülü, 2018: 105), Akfırat (Akfırat, 2010: 310) ve Yıldız'ın (Yıldız, 2014:65) çalışmalarından yararlanılmıştır. Soruların değerlendirilmesi için (1=asla, 2=nadiren, $3=$ ara sıra, 4=sıklıkla, 5=her zaman) olan 5'li Likert ölçeği kullanılmıştır. Hem soruların oluşturulmasında hem de asla ile başlayıp her zaman ile biten 5'li Likert'in oluşturulmasında siyasal katılım konusunda siyaset 
bilimcilerin çalışmalarından yararlanılmıştır (Dursun, 2012: 237; Çam, 2011: 169-172; Kapani, 2012: 147; Daver, 1993: 210; Baykal, 1970: 33; Öztekin, 2014: 240-243). Çalışmanın ölçek kısmında ise Milbrath (1965), Burkhart, Velasquez (2012), Rice- Moffet-Madupalli (2012), Vacarr (2013) ve Rozell-Mager'in incelemesini yapan ve aktaran Görgülü, Elciyar, Meriç, Tekin'den yararlanılmıştır (Meriç, 2014: 210; Tekin, 2015: 59).

“Siyasal Katılımda Sosyal Ağların Rolü: Üniversite Öğrencileri Üzerine Bir Araştırma” başlıklı yüksek lisans tezi kapsamında hazırlanan bu ölçek çalışması için, Burdur Mehmet Akif Ersoy Üniversitesi Etik Kurulundan 2019/107 sayılı ve 12.06.2019 tarihli “Etik Kurul Onayı” alınmıştır.

\section{Araştırmanın Analizi}

Çalışmanın istatiksel analizinde güvenirlik, geçerlilik ve normallik testi yapılmıştır. Çalışmanın güvenirlik testi için güven aralığı $\alpha=0,05$ ile 1,00 arası değer baz alınmıştır (Arslantürk, 2013: 172). Çalışmada öncelikle anket verilerinin güvenirlilik analizi yapılmıştır. Analiz sonucunda güvenirlik testinin Cronbach's Alpha katsayısı ölçeği 0,922 olarak bulunmuştur. Bu nedenle a değeri 0,80 ile 1,00 aralığında olduğu (Arslantürk, 2013: 174) için verileri ile ölçeğin mükemmel derecede güvenilir olduğu tespit edilmiştir.

Çalışmanın güvenirliği kesinleştikten sonra ölçülmek istenen şeyin ölçülebilmiş olma derecesi anlamına gelen geçerlilik testi yapılmıştır (Kartal ve Bardakçı, 2019: 52). Geçerlilik testinin istatiksel olarak ifade edilebilmesi için geçerliliği ölçen faktör analizi açısından ele alınmıştır. Faktör analizi, kısaca bir ölçeği oluşturan soruların, aynı sorunu ölçmeye yarayan sorulardan olup olmadığı veya farklı soruları çözüyorsa, bu soruların hangileri olduğunu belirlemek için kullanılan tekniktir (Ergün, 1995: 221). Çalışmaya uygun olan ve faktör analizinin türü olan yapısal geçerlilik analizi tercih edilmiştir. Çünkü yapısal geçerlilik analizi, ölçülmek istenen bir sorunun ve kurumun yapısına ilişkin ortaya konmak istenen özelliklerin bilimsel olarak gösterilmesidir (Arslantürk, 2013: 174). Bahsedilen Yapısal faktör analiz yöntemi açımlayıcı (AFA) ve doğrulayıcı (DFA) olarak ayrılmaktadır. Açımlayıcı faktör analizi araştırmayı oluşturan sorular arasında var olan yapıyı ortaya çıkarmak için kullanılırken, doğrulayıcı faktör analizi ise sorular için bahsedilen yapının önceden kararlaştırılmış kurum veya geçmiş yıllara kadar dayanan soruların var olduğunu ve bunların analiz edilebilmesi için kullanılan tekniklerdir (Uyumaz vd., 2016: 660). Açımlayıcı ve doğrulayıcı faktör analizlerinin yorumlanması için Kaiser-Meyer-Olkin (KMO) ve Barlett testi kullanılmaktadır.

Kaiser-Meyer-Olkin (KMO), verilerin tutarlı olup olmadığını ölçmek için kullanılmaktadır. Kaiser-Meyer-Olkin (KMO) değeri ne kadar yüksek olursa verilerin geçerliliği o kadar yüksek

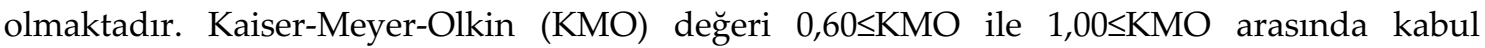
edilmektedir. Barlett testi ise veri örneklerinin eşit derecede değişkenlik özelliği olup olmadığını test etmek için kullanılmaktadır. Barlett testinin değeri $\mathrm{P} \leq 0,05$ ise verilerin bu test için uygun olduğunu göstermektedir (Yurdagül, 2019: 2).

Yukarıda bahsedilen testlerin yapılması sonucunda araştırmanın Kaiser-Meyer-Olkin (KMO) değeri 0,95 ve Barlett testi sonucu ise 0,00 olarak elde edilmiştir. Diğer bir deyişle araştırmanın verilerini oluşturan sorular mükemmel derecede geçerlidir.

Araştırmanın güvenirlik ve geçerlilik testinden sonra, araştırma için önemli olan normallik testi de kullanılmıştır. Normallik testi verilerin normal olarak dağılıp dağılmadığını göstermek için kullanılan analizdir (Arslantürk, 2013: 175-176). Verilerin normal dağılıp dağılmadığını ortaya koymak için verinin Skewness (Çarpıklık) ve Kurtosis (Basıklık) değerine bakılmaktadır. Araştırmanın normal dağılabilmesi için skewness ve kurtosis değerlerinin +-2 aralığında olması 
gereklidir (George ve Mallaey, 2010: 8). Araştırmanın normallik testi sonucunda, bütün soruların skewness ve kurtosis değerinin +-2 aralığında olduğu görülmüştür. Bu sonuca göre araştırmanın verileri normal dağılım göstermektedir.

\section{Araştırmanın Bulguları}

Yapılan alan araştırması sonucunda öğrencilerin sorulara verdikleri yanıtlar doğrultusunda elde edilen veriler tablolaştırılmıştır. Araştırmanın demografik bulgularına göre; ankete katılan öğrencilerin \%64.0'ü kadın, \%36.00 ise erkek katılımcıdır. Bu da kadın öğrencilerin, erkek öğrencilere göre bilimsel araştırmaya katılma açısından daha istekli olduğu şeklinde yorumlanabilir. Ayrıca 21-24 yaş aralığı \%72.3, 17-20 yaş aralığ $\% 23.0,25-28$ aralığ $1 \% 3.5$ ve diğeri $\% 0.5$ şeklinde dağılım göstermektedir. Bu verilere bakıldığında siyasal katılımda yaş ilerledikçe katılımın artığını görüşü desteklenmektedir. Gelire bakıldığında 164 katılımcının 350-500 TL, 152 katılımcının 500-1000 TL, 39 katılımcinın 1000-1500 TL, 12 katılımcinın 1500-2000 TL gelir aralığında, 33 katılımcının ise 2000 TL ve üstü gelir aralığında olduğu saptanmıştır. Öğrencilerin gelir açısından ülkenin ekonomisi göz önüne alındığında, ülkenin ekonomik yapısına uygun dağıldığı görülmektedir. Ankete katılan öğrencilerin bölüm sıralaması siyaset bilimi ve kamu yönetimi, işletme, bankacılık ve finansman, sağlık yönetimi, sosyal hizmet ve iktisattır. Öğrencilerin bölüm verilerine göre siyasal katılım ve diğer konular hakkında bilgi sahibi olan bölümlerde katılım açısından daha aktif bir tutum görülmüştür. Annenin eğitim durumu ile ilgili demografik verilere göre, en yüksek ilkokul mezunundan başlayarak, lise ve dengi, ortaokul ve dengi okuryazar değil, üniversite mezunu ve yüksek lisans ve doktora mezunu şeklinde sıralanmaktadır. Annenin mesleki sıralaması ise ev hanımı, diğeri, serbest meslek, çiftçi, memur, esnaf ve işsiz şeklindedir. Babanın eğitim durumu ise ilkokul mezunu, lise ve dengi, ortaokul ve dengi, üniversite mezunu, okuryazar değil, yüksek lisans ve doktora şeklindedir. Son olarak babanın mesleki durumu ise diğeri, serbest meslek, esnaf, memur, çiftçi ve işsizdir. Demografik özelliklerin değerlendirilmesinin ardından oluşturulan tablolar soruların içerisindeki özellikler çerçevesinde belirli gruplara ayrılarak değerlendirilmiştir.

Genel olarak yapılan faktör analizi sonucunda analiz açısından daha verimli sonuçlar alabilmek için üç ana faktör grubu oluşturulmuştur. Çünkü ankette yer alan sorular temelde iletişim, paylaşım ve katılım davranışlarını ölçmeye yönelik olarak kendi içerisinde dağılım göstermektedir. Bunlar iletişim grubu, paylaşım grubu ve katılım grubu şeklinde aşağıda tablolarda ayrıntılı şekilde açıklanmıştır.

Aşağıda tablodaki yer alan sorular kendi içlerinde gösterdikleri özelliklerden dolayı gruplandırılmıştır. Bu ilk grup soruların ortak özelliği olan iletişim kavramından yola çıkılarak iletişim grubu olarak ayrılmıştır. Öğrencilere yöneltilen bu soruların bulguları ise şunlardır;

Tabloda yer alan bir siyasal kişinin veya siyasal grubun sosyal ağ hesabımı ziyaret ederim sorusuna \% 24.0 ara sıra, \% 20.3 ise sıklıkla cevabını vermiştir. Bu da öğrencilerin siyasal katılımla ilgili bir davranışı sosyal ağlarda kullandığını göstermektedir. Elde edilen bu veriye göre herhangi bir siyasal figür, siyasi grup vs. açısından öğrencinin beğendiği sosyal ağ hesaplarını ziyaret ettiği fakat aktif tutumdan zaman zaman uzaklaştığı şeklinde yorumlamak mümkündür.

Tabloda yer alan seçilmiş bir yetkiliyle sosyal ă̆ üzerinden iletişime geçerim sorusuna \% 48.8 asla cevabını verdiği görülmektedir. Bu sonuca göre öğrencilerin, siyasetle ilgili herhangi bir konuda kendileri tarafından seçilmiş olan siyasal bir yetkiliyle bile iletişime geçmek istemediği görülmektedir. 
Tablo 1. İletişim Grubunun Sosyal A $\breve{g}$ ve Siyasal Katılımına Ait Analizi

\begin{tabular}{|c|c|c|c|c|}
\hline \multirow{17}{*}{$\begin{array}{l}\text { İletişim } \\
\text { Grubu }\end{array}$} & Anket Soruları & $\begin{array}{l}\text { 5'li Likert } \\
\text { Özelliği }\end{array}$ & $\mathrm{F}$ & $\%$ \\
\hline & \multirow{2}{*}{$\begin{array}{l}\text { Bir siyasal kişinin veya siyasal } \\
\text { grubun sosyal ağ hesabını ziyaret } \\
\text { ederim }\end{array}$} & Ara Sira & 96 & 24.0 \\
\hline & & Siklıkla & 81 & 20.3 \\
\hline & \multirow{2}{*}{$\begin{array}{l}\text { Seçilmiş bir yetkiliyle sosyal ağ } \\
\text { üzerinden iletişime geçerim. }\end{array}$} & Asla & 195 & 48.8 \\
\hline & & Her Zaman & 88 & 22.0 \\
\hline & \multirow{2}{*}{$\begin{array}{l}\text { Bir siyasal parti veya siyasetçinin } \\
\text { kullandiğı sosyal ağ sayfasını } \\
\text { beğenirim. }\end{array}$} & Asla & 92 & 23.0 \\
\hline & & Her Zaman & 72 & 18.0 \\
\hline & \multirow{2}{*}{$\begin{array}{l}\text { Bir siyasal parti veya siyasetçiyi } \\
\text { sosyal ağlarda arkadaş olarak } \\
\text { eklerim, takip ederim }\end{array}$} & Asla & 102 & 25.5 \\
\hline & & Her Zaman & 144 & 40.0 \\
\hline & \multirow{2}{*}{$\begin{array}{l}\text { Sosyal ağlarda benzeri görüşe } \\
\text { sahip diğer kullanıcıları takip } \\
\text { ederim, arkadaş eklerim. }\end{array}$} & Asla & 117 & 27.8 \\
\hline & & Her Zaman & 111 & 29.3 \\
\hline & \multirow{2}{*}{$\begin{array}{l}\text { Sosyal ağlarda zıt görüşe sahip } \\
\text { diğer kullanıcıları takip ederim, } \\
\text { arkadaş eklerim }\end{array}$} & Asla & 129 & 32.3 \\
\hline & & Her Zaman & 95 & 22.8 \\
\hline & \multirow{2}{*}{$\begin{array}{l}\text { Siyasal olaylar sonucunda karar } \\
\text { alıcılara erişerek sosyal ağ yoluyla } \\
\text { baskı altına almaya çalışırım. }\end{array}$} & Asla & 228 & 57.0 \\
\hline & & Her Zaman & 88 & 20.3 \\
\hline & \multirow{2}{*}{$\begin{array}{l}\text { Siyasal olaylar doğrultusunda } \\
\text { insanları sosyal ağ aracılığıyla } \\
\text { harekete geçiririm }\end{array}$} & Asla & 198 & 49.5 \\
\hline & & Her Zaman & 88 & 22.1 \\
\hline
\end{tabular}

Öğrencilere yöneltilen bir siyasal parti ve siyasetçinin kullandiğı sosyal ă̆ sayfalarım beğenirim sorusuna \% 23.0 asla cevabını, \% 18 her zaman cevabını vermiştir. Diğer cevaplara bakıldığında aralarında çok fark olmadığı görülmektedir. Yani bu soruda diğerlerinden farklı olarak öğrencilerin siyasal katılımla ilgili bir davranışı gerçekleştirmek için sosyal ağları kullandığı görülmektedir. Ayrıca öğrenciler bir siyasal parti ve siyasetçiyi sosyal ağlarda arkadaş olarak eklerim, takip ederim sorusuna \%40 her zaman cevabı vermiştir. Burada da bir önceki sorudaki gibi öğrencilerin siyasal katılımla ilgili bir davranışı sosyal ağlar üzerinde kullandıkları görülmüştür.

Sosyal ağlarda benzer görüşe sahip kullanıcıları takip ederim, arkadaş olarak eklerim sorusuna \% 27.8 asla cevabını vermiştir. Bu da öğrencilerin kullandıkları sosyal ağlarda siyasi olarak kendi görüşlerini içerseler dahi arkadaş olarak farklı kimseyi istemediğini göstermektedir.

Tabloda yer alan sosyal ağlarda zıt görüşe sahip diğer kullanıcıları takip ederim, arkadaş olarak eklerim sorusuna \% 32.3 asla cevabını vermiştir. Öğrenciler bir önceki soruda yer alan bir siyasal parti ve siyasetçiyi sosyal ağlarda arkadaş olarak eklerim, takip ederim sorusuna çoğunluğu her zaman cevabını vererek bu siyasal katılım davranışını sosyal ağlar üzerinden gerçekleştirdiğini göstermiştir. Ancak yine bu soruya öğrenciler yüksek oranda asla cevabını vererek kullandıkları sosyal ağlarda siyasi olarak kendi görüşlerinin dışında farklı görüşlere sahip kişileri arkadaş olarak istemediklerini göstermişlerdir.

Tabloda yer alan başka bir soru olan siyasal olaylar sonucunda karar alıcllara erişerek sosyal ă̆ yoluyla baskı altına almaya çalışırım sorusuna ise \% 57.0 asla cevabını vermiştir. Bu da öğrencilerin siyasal 
olayları takip ettiğini ancak gündemde olan siyasal bir olay için farklı gerekçelerden dolayı, siyasetçiler ile iletişime geçerek onları etkilemek istemediklerini göstermektedir.

$\mathrm{Bu}$ grubun son sorusu olan siyasal olaylar doğrultusunda inşaları sosyal ă̆ aracılı̆̆gyla harekete geçiririm sorusuna \% 49.5 asla cevabını vermiştir. Bu da öğrencilerin gündemde olan siyasal bir olay için sosyal ağı kullanarak toplumu etkilemek istemediğini göstermektedir.

İletişim grubunda yer alan soruların bulgularına bakıldığında genel olarak öğrencilerin sosyal ağlarda yer alan siyasal katılım olaylarını takip ettikleri, bu olaylar hakkındaki görüşlerinin çeşitli sebeplerden dolayı başkaları tarafından bilinmesini istemedikleri için sosyal ağlarda kendi görüşleri hakkında bilgi veya bilgi yerine geçen herhangi bir şey paylaşmak istemedikleri sonucu ortaya çıkmıştır. Benzer bir sonuç Çağlar ve Asığbulmuş (2017), X ve Y kuşaklarının siyasal davranışında sosyal medyanın etkisini Gaziosmanpaşa özelinde incelediği çalışmada görülmüştür. Katılımcılarının siyasal konu hakkında düşüncelerinin bilinmesini istemediği sonucuna ulaşmışlardır (Çağlar ve Asığbulmuş, 2017:107).

Tablo 2. Paylaşım Grubunun Sosyal A ̆g ve Siyasal Katılımına Ait Analizi

\begin{tabular}{|c|c|c|c|c|}
\hline \multirow{17}{*}{$\begin{array}{l}\text { Paylaşırım } \\
\text { Grubu }\end{array}$} & Anket Soruları & $\begin{array}{l}\text { 5'li Likert } \\
\text { Özelliği }\end{array}$ & $\mathrm{F}$ & $\%$ \\
\hline & \multirow{2}{*}{$\begin{array}{l}\text { Bir siyasal konu hakkında } \\
\text { görüşlerimi cevrim içi olarak } \\
\text { paylaşırım. }\end{array}$} & Asla & 121 & 33.1 \\
\hline & & Siklıkla & 105 & 23.3 \\
\hline & \multirow{2}{*}{$\begin{array}{l}\text { Bir sosyal ağ sayfasında siyasetle } \\
\text { ilgili yorumlar paylaşırım. }\end{array}$} & Asla & 185 & 46.3 \\
\hline & & Siklıkla & 88 & 22.1 \\
\hline & \multirow{2}{*}{$\begin{array}{l}\text { Siyasal konular hakkında durum } \\
\text { güncellemesi yaparım. }\end{array}$} & Asla & 152 & 34.0 \\
\hline & & Siklıkla & 108 & 27.1 \\
\hline & \multirow{2}{*}{$\begin{array}{l}\text { Siyasal etkinliğe katıldığımı } \\
\text { sosyal ağda paylaşırım. }\end{array}$} & Asla & 189 & 47.3 \\
\hline & & Her Zaman & 90 & 22.5 \\
\hline & \multirow{2}{*}{$\begin{array}{l}\text { Sosyal ağlarda bir siyasal } \\
\text { konunun yayılması için } \\
\text { paylaşım yaparım }\end{array}$} & Asla & 187 & 46.0 \\
\hline & & Her Zaman & 97 & 24.3 \\
\hline & \multirow{2}{*}{$\begin{array}{l}\text { Sosyal ağlarda hesap ismimi } \\
\text { siyasi görüşümü belirten } \\
\text { eklemeler yaparak paylaşırım }\end{array}$} & Asla & 267 & 66.8 \\
\hline & & Her Zaman & 66 & 16.5 \\
\hline & \multirow{2}{*}{$\begin{array}{l}\text { Sosyal ağ üzerinden karşıt } \\
\text { görüşler hakkında olumsuz } \\
\text { içerik paylaşırım }\end{array}$} & Asla & 239 & 59.8 \\
\hline & & Her Zaman & 69 & 17.3 \\
\hline & \multirow{2}{*}{$\begin{array}{l}\text { Siyasal Konular Hakkında } \\
\text { Sosyal Ağlarda Notlar } \\
\text { Paylașırım }\end{array}$} & Asla & 190 & 47.5 \\
\hline & & Her Zaman & 90 & 22.6 \\
\hline
\end{tabular}

Yukarıdaki tabloda yer alan sorular kendi içlerinde gösterdikleri özelliklerden dolayı gruplandırılmıştır. İkinci grup soruların ortak özelliğinden dolayı bu sorularda ortak olan paylaşım eyleminden yola çıkılarak paylaşım grubu olarak ayrılmıştır. Bu sorularla ilgili bulgular ise şunlardır;

Tabloda yer alan bir siyasal konu hakkında görüşlerimi çevrimiçi olarak paylaşırım sorusuna \% 33.1 asla cevabını vermiştir. Burada iletişim grubunda yer alan sorulara verilen cevaplara yakın bir 
sonuç olduğu görülmüştür. Yani bu sonuç öğrencilerin kendi düşüncelerini yayımlamaktan çekindiklerini göstermektedir. Ancak tabloda yer alan bir sosyal ă̆g sayfasında siyasetle ilgili yorumlar paylaşırım sorusuna öğrencilerden \% 46.3'ü asla cevabıyla bir sosyal ağ sayfasında siyasetle ilgili yorum paylaşımında bulunmadıklarını ifade etmişlerdir.

Öğrencilere yöneltilen siyasal konular hakkında durum güncellemesi yaparım, paylaşırım sorusuna öğrencilerin \% 34.0’ü asla cevabıyla siyasal konular hakkında durum güncellenmesinde bulunmadıklarını belirtmişlerdir. Bir önceki sorudaki gibi siyasetle ilgili görüşlerin bilinmesini istememektedirler. Ayrıca öğrenciler siyasal etkinliğe katıldığımı sosyal ağlarda paylaşırım sorusuna da çoğunluğu yani \% 47.3'ü asla cevabını vermiştir. Bu da daha öncekiler gibi öğrencilerin katıldıkları veya katılmayı düşündükleri siyasal bir eylemin başkaları tarafından bilinmesini istemediklerini göstermektedir. Bunda toplumdaki diğer bireylerin katıldıkları siyasal eylemler hakkında olumsuz bir tavır gösterebileceği düşüncesi etkili olabilmektedir.

Öğrenciye yöneltilen diğer paylaşım sorusu olan sosyal ağlarda bir siyasal konunun yayılması için paylaşım yaparım sorusuna ise \% 46.0 asla cevabını vermiştir. Bu cevap öğrencilerin sosyal ağlar üzerinden herhangi bir konunun yayılmasını sağlayarak aktivist bir tutum sergilemekten kaçındıklarını göstermektedir.

Sosyal ağlarda hesap ismimi siyasi görü̧̧ümü belirten eklemeler yaparak paylaşırım sorusuna ise öğrenciler bir önceki soruyla aynı cevabı vermişlerdir. Burada öğrencilerin profillerini siyasal görüşlerine göre güncellememekte olduğu görülmüştür. Diğer bir soru olan sosyal ağ üzerinden karşıtlı görü̈sler hakkında olumsuz içerik paylaşırım sorusuna katılanların \% 59.8'i asla olarak cevap vermiştir. Bu durum öğrencilerin siyasal konu hakkında sosyal ağlarda birbirlerine karşı saygılı olduklarını göstermektedir. Ayrıca öğrenciler siyasal konular hakkında sosyal ağlarda notlar paylaşırım sorusuna \% 47.5 asla cevabını vermiş̧ir. Öğrencilerin siyasal bir konu hakkındaki düşüncelerinin başkaları tarafından bilinmesini istememekte olduğu görülmektedir.

Yukarıdaki bulgulardan yola çıkılarak paylaşım grubunda yer alan sorulara öğrencilerin genel olarak asla cevabını verdikleri görülmektedir. Buna göre, sosyal ağ ve siyasal katılım ilişkisini ortaya koyan ve sosyal ağlarda eylem olarak paylaşım içeren sorulara verilen cevaplar değerlendirildiğinde diğer çalışmalardan farklı olarak sosyal ağ ve siyasal katılım ilişkisi açısından paylaşım gurubundaki sorularda bir ilişki olmadığı görülmüştür. $\mathrm{Bu}$ sonucu destekleyici şekilde ulusal literatürde çalışmalar da görülmüştür. Şener, Emre ve Akyıldız (2015) Türkiye'de sosyal medyanın siyasi katılıma etkisini incelemişler, katılımcıların büyük çoğunluğunun sosyal ağlar üzerinden siyasal görüşlerini paylaşmayı tercih etmediğini tespit etmişlerdir. Çalışmanın bulgularıyla örtüşmektedir (Şener, Emre ve Akyıldız, 2015: 94-95).

Aşağıdaki anket verilerine göre öğrencilerin \% 37.8'i siyasete ilgi duymaktayım sorusuna sıklıkla ilgili duydukları görülürken, azımsanmayacak kesim olan \% 34.5 ise siyasete ara sıra ilgili duyduklarını dile getirmişlerdir. Ancak genel olarak öğrencilerin hem ulusal hem de uluslararası siyasal olaylara ilgili oldukları söylenebilir.

Tabloda yer alan siyasetle ilgili konularda ailem ve arkadaşlarımla konuşurum değişkenine \% 46.3 bu davranışı sıklıkla yaptıklarını ifade etmiştir. \% 30 ise ara sıra konuştuğunu belirtmiştir. Bu sonuca göre genel olarak öğrenciler siyasal düşüncelerini ve fikirlerini güvendikleri ortamlarda paylaşmaktan çekinmemektedir.

Öğrencilere yöneltilen sosyal ăg uygulamalarından en sık facebook, instagram, youtube, twitter'ı kullanırım sorusuna \% 80.4 her zaman cevabını vermiştir. Bu durumda sosyal ağların yaygın olarak kullanıldığı görülmektedir. Ancak dijital teknolojinin ve bilgi iletişim teknolojilerinin çok hızlı geliştiği ve yaygın olduğu zamanlarda bile \% 10.3'ü asla cevabını vermiştir. Bu cevabı veren 
öğrencilerin dijital ortama duyduğu güvensizlik, sahip oldukları kişilik özelliği, tercih vb. çeşitli nedenlerden dolayı sosyal ağları kullanmadıkları söylenebilir.

Tablo 3. Katılım Grubunun Sosyal A $\breve{g}$ ve Siyasal Katılımına Ait Analizi

\begin{tabular}{|c|c|c|c|c|}
\hline \multirow{31}{*}{$\begin{array}{l}\text { Katilım } \\
\text { Grubu }\end{array}$} & Anket Soruları & $\begin{array}{l}\text { 5'li Likert } \\
\text { Özelliği }\end{array}$ & $\mathrm{F}$ & $\%$ \\
\hline & \multirow[t]{2}{*}{ Siyasete ileri derecede ilgi duymaktayım. } & Ara Sira & 130 & 34.5 \\
\hline & & Sıklıkla & 153 & 37.8 \\
\hline & \multirow{2}{*}{$\begin{array}{l}\text { Siyasetle ilgili konularda ailem ve } \\
\text { arkadaşlarımla konuşur. Düşüncelerimi } \\
\text { dile getiririm. }\end{array}$} & Ara Sira & 120 & 30.0 \\
\hline & & Siklıkla & 185 & 46.3 \\
\hline & \multirow{2}{*}{$\begin{array}{l}\text { Sosyal ağ uygulamalarından en sık } \\
\text { facebook, instagram, youtube, twitter } \\
\text { kullanırım. }\end{array}$} & Ara Sira & 41 & 10.3 \\
\hline & & Her Zaman & 321 & 80.4 \\
\hline & \multirow{2}{*}{$\begin{array}{l}\text { Siyasetle ilgili gelişmeleri sosyal ağlardan } \\
\text { öğrenirim. }\end{array}$} & Ara Sira & 98 & 24.5 \\
\hline & & Siklıkla & 256 & 64.1 \\
\hline & \multirow{2}{*}{$\begin{array}{l}\text { Sosyal ağlardaki siyasal etkinlikler } \\
\text { siyasetle ilgili davranışları etkiler ve } \\
\text { katılıma teşvik eder. Örneğin oy } \\
\text { kullanmak gibi }\end{array}$} & Nadiren & 81 & 20.3 \\
\hline & & Siklıkla & 199 & 49.8 \\
\hline & \multirow{2}{*}{$\begin{array}{l}\text { Sosyal ağlarda kullanılan katılım } \\
\text { davranışlarını siyasetçiler üzerinde etkili } \\
\text { olur }\end{array}$} & Ara Sira & 108 & 27.0 \\
\hline & & Siklıkla & 185 & 46.3 \\
\hline & \multirow{2}{*}{$\begin{array}{l}\text { Siyasal amaçlı sosyal ağlarda imza } \\
\text { kampanyalarına katılırım (change.org vb.) }\end{array}$} & Asla & 185 & 44.3 \\
\hline & & Siklıkla & 86 & 21.5 \\
\hline & \multirow{2}{*}{$\begin{array}{l}\text { Bir siyasal parti veya siyasetçi için sosyal } \\
\text { ağlarda bağış kampanyasına katılııım }\end{array}$} & Asla & 220 & 55.5 \\
\hline & & Her Zaman & 75 & 17.6 \\
\hline & \multirow{2}{*}{$\begin{array}{l}\text { Siyasal davranışı belirtmek için konum } \\
\text { paylaşımına katılırım (Swarm vb.) }\end{array}$} & Asla & 224 & 54.0 \\
\hline & & Siklıkla & 81 & 20.3 \\
\hline & \multirow[t]{2}{*}{ Siyasal konular hakkında blog yazarım } & Asla & 236 & 59.0 \\
\hline & & Her Zaman & 75 & 18.5 \\
\hline & \multirow{2}{*}{$\begin{array}{l}\text { Siyasal konular hakkında internet } \\
\text { haberlerine yorum yazarım }\end{array}$} & Asla & 210 & 52.5 \\
\hline & & Her Zaman & 91 & 22.8 \\
\hline & \multirow{2}{*}{$\begin{array}{l}\text { Sosyal ağlarda siyasal içerikli mizah } \\
\text { unsurları üretirim (caps, montaj, gif) }\end{array}$} & Asla & 210 & 52.5 \\
\hline & & Her Zaman & 92 & 23.0 \\
\hline & \multirow{2}{*}{$\begin{array}{l}\text { Wiki, sözlük gibi sitelerde siyasal konular } \\
\text { hakkında başlık açarım }\end{array}$} & Asla & 256 & 62.8 \\
\hline & & Her Zaman & 72 & 18.1 \\
\hline & \multirow{2}{*}{$\begin{array}{l}\text { Sosyal ağlarda profil resmimi siyasal } \\
\text { olaylara uygun olarak değiştirme } \\
\text { eylemlerine katılırım }\end{array}$} & Asla & 153 & 38.3 \\
\hline & & Siklıkla & 94 & 26.6 \\
\hline & \multirow{2}{*}{$\begin{array}{l}\text { Sosyal ağlarda siyasi nitelikli bir } \\
\text { tartışmaya katılırım }\end{array}$} & Asla & 213 & 53.3 \\
\hline & & Her Zaman & 76 & 19.1 \\
\hline
\end{tabular}

Öğrencilere yöneltilen, siyasetle ilgili gelişmeleri sosyal ağlardan öğrenirim sorusuna öğrencilerin \%64.1'i sı sıklıkla cevabını vermiştir. Bu ise öğrencilerin sosyal ağları kullanarak gündemdeki her şeyi çabuk öğrendiklerini göstermektedir. Ayrıca önceki sorulara bakıldığında öğrencilerin 
siyasetle ilgili herhangi bir konu için sosyal ağları kullandıkları, kendi görüşlerini ortaya koymak için ise sosyal ağı kullanmamayı tercih ettikleri görülmüştür. Yani sosyal ağları siyasetle ilgili bilgi aracı olarak görmektedirler.

Tabloda yer alan sosyal ağlardaki siyasal etkinlikler, siyasetle ilgili davranışları etkiler ve katılıma teşvik eder sorusuna öğrencilerin \% 49.8'i sıklıkla cevabını seçerek sosyal ağlardaki siyasal konular hakkında yapılan etkinliklerin siyasete katılımı etkilediğini ortaya koymaktadır. Öğrencilerin siyasal katılımda sosyal ağların etkili olduklarını düşündükleri görülmüştür. Buradaki sonuçla örtüşür şekilde Temel, Önürmen ve Köprü (2014), seçim kampanyalarında dijital araçlar ve internetin yerini üniversite öğrencileri üzerine yaptıkları araştırma ile ölçtükleri çalışmalarında siyasal katılımda takip etme, bilgi alma konularında sosyal ağların etkili olduğu sonucuna varmışlardır (Temel, Önürmen ve Köprü 2014: 335-336). Ancak kişisel ya da diğer nedenlerden dolayı sosyal ağları bu amaçla kullanmak istemedikleri söylenebilir.

Sosyal ağlarda kullanılan katılım davranışları siyasetçiler üzerinde etkili olur sorusuna ise öğrencilerin \% 46.3 'ü sıklıkla cevabını vererek sosyal ağlarda kullanılan katılım davranışlarının siyasetçiler üzerinde etkili olduğu düşüncesini yaygın olarak kabul ettiği görülmüştür.

Siyasal amaçlı sosyal ağlarda imza kampanyalarına katılırım sorusuna \% 44.3 asla cevabını vermiştir. Burada önceki sorulardan elde edilen sonuçlardan farklı bir sonuç ortaya çıkmıştır. Yani öğrencilerin siyasal bir eylem olan bir davranışa katılmak istemediğini göstermektedir. Öğrencilerin sıklıkla kullandıkları sosyal ağlarda siyasal katılım olan hiçbir eylemin başkaları tarafından bilinmesinin istenmediğini göstermektedir. Bunun nedeni onlar tarafından dışlanabilecekleri düşüncesinden kaynaklanabilmektedir.

Ankette yer alan, sosyal ağlarda siyasi nitelikli bir tartışmaya katılırım değişkenine \%53.3 asla cevabını vermiştir. Bu durum öğrencilerin siyasetle ilgi tartışmaların yer aldığı sosyal ağ ortamında bulunmak istemediklerini göstermektedir. Sosyal ağlardaki ortamların güvenli olmadığ 1 düşüncesi bunda etkili olabilir. Başka bir soru olan bir siyasal parti veya siyasetçi için sosyal ağlarda bă̆ış kampanyalarına katılırım sorusuna \%55.5 asla cevabını vermiştir. Öğrencilerin siyasal bir katılım eylemi olan bir davranışa katılmak istemediği açıkça görülmektedir.

Tabloda yer alan sosyal ağlarda profil resmimi siyasal olaylara uygun olarak değiştirme eylemlerine katılırım sorusuna \%38.3 asla cevabını vermiştir. Öğrencilerin siyasal bir katılım eylemi olan bu davranışa sosyal ağlar üzerinden katılım sağlamak istemediğini göstermektedir. Ayrıca öğrencilere yöneltilen siyasal davranışları belirtmek için konum paylaşımına katılırım sorusuna da $\% 54.0$ asla cevabını vermiştir. Bu durum öğrencilerin siyasal bir katılım eylemini gerçekleştirdikleri sırada paylaşım yaparak konumunun bilinmesini istemediğini göstermektedir.

Siyasal konular hakkında blog yazarım sorusuna bakıldığında daha öncekilere benzer şekilde bu soruya \%59.0 asla cevabını vermiştir. Bu da öğrencilerin siyasal bir konu hakkındaki düşüncelerini bir eyleme dökmek istemediğini göstermektedir.

Tabloda yer alan siyasal konular hakkında internet haberlerine yorum yazarm sorusuna \%52.5 asla cevabını vermiştir. Öğrenciler gündemdeki bir siyasal olay hakkında düşüncelerinin bilinmesini istememektedir.

Sosyal ağlarda siyasal içerikli mizah unsurları üretirim sorusuna \%52.5 asla cevabını vermiştir. Öğrencilerin bir siyasal olay hakkında bir şeyler üretmek istemediği sonucu ortaya çıkmıştır. Başka bir soru olan wiki, sözlük gibi sitelerde siyasal konular hakkında başlık açarım ve katılım sağlarım sorusuna ise \% 62.8 asla cevabını vermiştir. Bu da öğrencilerin siyasal konular hakkında sosyal ağlarda bir katılım yapmak istemediklerini göstermektedir. 
Benzer şekilde Doğu (2014), siyasetin yeni halini değerlendirdiği araştırmasında katılımcıların siyasi partileri, particileri ve siyasi aktörleri takip ettiklerini fakat siyasal görüşleri hakkında sosyal ağlarda iletişime geçmek istemediklerini tespit etmiş̧tir (Doğu, 2014: 150-155).

Görüldüğü gibi katılım grubunda yer alan anket sorularına öğrencilerin verdiği cevaplara bakarak, genel olarak öğrencilerin siyasete ilgili duydukları, siyasetle ilgili haberleri sosyal ağlardan öğrendikleri ancak siyasal bir konu hakkında düşünce, eylem ve işlemleri sosyal ağlar üzerinden gerçekleştirmek istemedikleri sonucuna ulaşılmıştır.

\section{SONUÇ ve DEĞERLENDİRME}

Siyasal katılım, oy kullanma, yerel yönetimi ve seçilenleri denetleme ve yöneticileri seçme gibi eylemleri kapsamaktadır. Ancak günümüzde yaygın olarak siyasal katılım vatandaşın yerel ve merkezi düzeyde kendisini hem ülke içinde hem de ülke dışında temsil edecek kişileri düşünmelerinden başlayıp seçtikten sonra seçilenleri her türlü araçla takip edip beğendiği beğenmediği, şikâyetçi olduğu veya olmadığı konular hakkında yapılan döngüsel eylem ve sözleri içermektedir.

Sosyal ağ kavramı ise değişik evreler geçirerek bu zamana kadar gelen her türlü iletişim araçlarıdır. Belirtilen sosyal ağlar zamanla gelişim göstererek bireylerin hayattaki her alanında yer almaya başlamış hatta çoğu zaman vazgeçilemez hale gelmiştir. Sosyal ağların hayatı kuşattığı alanlardan bir tanesi de siyasal hayattır. Sosyal ağların bireylerin siyasal katılım davranışları üzerine etkisi olup olmadığı yönünde yapılan bu araştırmanın, temel sorusu ve amacı bunu ortaya koyabilmektir. Farklı dönemlerde benzer çalışmalar yapılmış ve sonuçlar ortaya konmuştur.

Siyasal katılımda sosyal ağların etkisini tespit etmek için yapılan çalışmanın analizleri sonucunda genel olarak siyasal katılım ile sosyal ağlar arasında önceki çalışmalarda bahsedildiği türden yakın bir ilişki bulunamamıştır. Bu alanda yapılan çalışmalarla ilgili geniş kapsamlı literatür taraması yapılmış bu kapsamda yerli ve uluslararası akademik çalışmalar ve yayınlar incelenmiştir. Çalışmanın literatür kısmında da belirtildiği gibi bu çalışmalardan bazıları, Cevat Özyurt'un, Öğrencilerinin Siyasal Katılım Davranışları: 29 Mart 2009 Yerel Seçimleri Balıkesir Örneği, Fatma Dilber'in, Siyasal Katılımında Kitle İletişim Araçlarının Seçmenler Üzerine Etkisi: Karaman İli Seçmenler Üzerine Bir Alan Araştırması, Mehmet Celal Gültekin'in, Üniversite Öğrencilerinin Siyasal Katılım boyutlarının İncelenmesi; Mardin Örneği, Hamza Bahadır Eser' in, İnternet ve Sosyal Ağların Siyasal Katılım Üzerine Etkisi: SDÜ Örneği, Ali Fuat Gökçe, İlbey Özdemir ve İbrahim Halil Ceylan'ın; Üniversite Öğrencilerin Siyasal Katılım Seviyesi: Kilis 7 Aralık Üniversitesi Öğrencileri ve Osman Metin'in, Sosyal Medyanın Siyasal Toplumsallaşmaya Etkisi: Bir Alan Araştırması Örnekleri'dir. Dünya genelinde ise, Valenzuela, Park ve Kee'nin, Facebook kullanan öğrencilerin siyasal katılımı üzerine, Kim ve Kim tarafından hazırlanan yeni ve eski sosyal ağların siyasal katılım üzerine etkisi, Lewis'in blog kullananların çevrimiçi olmasının siyasal katılıma etkisi, Skoric ve Poor'un siyasal katılıma sosyal ağların etkisi üzerine, Evans ve Ubig'in, bireyin sosyallik düzeyi açısından siyasal katılım, Wolton 'un siyasal iletişim ile sosyal ağ arasındaki ilişkiden yola çıkarak siyasal katılımı açıkladığı çalışma vb. görülebilmektedir. Genel olarak bu çalışmaların çoğunluğu siyasal katılım ile sosyal ağ arasında anlamlı ve doğru orantılı bir ilişki bulmuştur. Ancak araştırmada siyasal katılım ile sosyal ağ kullanımı arasında anlamlı ve doğru orantılı bir ilişki bulunamamıştır.

Araştırmada sosyal ağlar ile siyasal katılım arasında anlamlı bir ilişki bulunamamasında araştırmanın yapıldığı dönem de etkili olabilmektedir. Dönemsel farklılıklar içerisinde, kuşaklar arası farklılıklar, ulusal ve uluslararası siyasetteki gelişmeler ve yaşanılan olaylar, çevresel ve 
ailesel faktörler gibi birçok neden etkili olabilmektedir. Örneğin, Z kuşağı olarak adlandırılan kuşak her ne kadar dijital bir çağın ortasına doğmuş olsa da sosyal medyayı ve iletişim teknolojilerini farklı niyetlerle (arkadaşlık, eğitim, kültür, haberleşme vb.) kullanmakta ve politik açıdan A politik olabilmektedir.

Araştırmada genel olarak öğrenciler, siyasal bir konu veya siyasal bir lideri sosyal ağlarda takip ederken, siyasal katılım hakkındaki düşüncelerinin kendi çevreleri ve sosyal ağlarda bilinmesini istememektedirler. Öğrencilerin siyasi konular hakkında konuşmak ya da herhangi bir faaliyette bulunmak ayıp ya da istenmeyen kötü bir davranış şeklindeki algısı siyasal katılımı azaltmaktadır. Fakat sosyal ağlar ve siyasal katılım konusu bölge, zaman, toplum, kültür ve mekan boyutları ile sürekli değişkenlik gösteren bir olgudur. Bu yönü ile sürekli araştırmaya ve yeni sonuçlara ulaşmaya açı bir alandır. Bu nedenle genel kanaat farklı dönemlerde farklı örneklem gruplarında yapılacak çalışmaların farklı sonuçlar ortaya koyabilme özelliği her zaman sayılan nedenlerden dolayı olabilecektir.

\section{KAYNAKÇA}

Akfırat, O. N. (2010). Türkiye ve Almanya'da Yaşayan Üniversiteli Türk Gençlerinin Siyasal ve Toplumsal Katılım Türlerinin ve Düzeylerini Belirleyen Etkenlerin Saptanması ve Karşılaştırılması, Yayınlanmamış Doktora Tezi, Ankara Üniversitesin Eğitim Bilimleri Enstitüsü, Ankara.

Alper, A. (2012). Sosyal Ağlar. Ankara: Pelikan Yayıncilık.

Arslantürk, Z. ve Arslantürk E. H. (2013). Uygulamalı Sosyal Araştırma, Kavramlar, Teknikler, Metotlar ve Bilgisayar Uygulamaları (SPSS). (3.Basım), İstanbul: Çamlıca Yayıncılık.

Aslan, P. (2011). Halkla İlişkilerde Yeni Eğilimler: Sosyal Medya. İstanbul: Marmara Üniversitesi Yayıncilik.

Ayan, B. (2016). Sosyal Ağlar Tarihi. İstanbul: Abaküs Yayıncılık.

Aydın, A. (2017). Sosyal Medya Paradigmasındaki Dönüşümün Siyasal Katılıma Yansıması, Yayınlanmamış Doktora Tezi, Mustafa Kemal Üniversitesi Sosyal Bilimler Enstitüsü Kamu Yönetimi Ana Bilim Dalı, Hatay.

Baykal, D. (1970). Siyasal Katılma: Bir Davranış İncelemesi. Ankara: Ankara Üniversitesi Yayıncllık.

Barber, R. B. (2003). Strong Democracy Participatory Politics for A New Age. England: University of California Press.

Çağlar, N. ve Asığbulmuş, H. (2017). X ve Y Kuşaklarının Siyasal Davranışında Sosyal Medyanın Etkisi: Gaziosmanpaşa İlçesinde Bir Araştırma, Süleyman Demirel Üniversitesi Sosyal Bilimler Enstitüsü Dergisi, 2017/4: 85-112.

Çam, E. (2011). Siyaset Bilimine Giriş. (10.Basım), İstanbul: DER Yayıncllı.

Çevikbaş, R. (2008). Yerel Yönetimlerde Siyasal Katılım. Türk İdare Dergisi, 461, 71-95.

Daver, B. (1993). Siyaset Bilimine Giriş. Ankara: Siyasal Yayıncllık.

Doğu, B., Özçetin, B., Bayraktutan, G., Binark, M., Çomu, T., Telli, Aydemir A. ve İslamoğlu, G. (2014). Siyasetin Yeni Hali: Vaka-i Sosyal Medya. İstanbul: Kalkedon Yayıncılık.

Dilber, F. (2012). Siyasal Katılımda Kitle İletişim Araçlarının Seçmenler Üzerine Etkisi; Karaman İli Seçmenler Üzerine Bir Alan Araştırması. E Journal of New World Siences Academy, 7: 154-191. 
Dursun, D. (2012). Siyaset Bilimi. (6.Basım), İstanbul: Beta Yayıncılık.

Eldeniz, L. (2010). İkinci Medya Çağında İletişimin Rolü ve Web 2.0. İkinci Medya Çağında İnternet. İstanbul: Alfa Yayıncilık.

Ergün, M. (1995). Bilimsel Araştırmalarda Bilgisayarlı İstatistik Uygulamalar: SPSS for Windows. (2.Basım), Ankara: Ocak Yayıncilık.

Eser, H.B. (2015). İnternet ve Sosyal Ağların Siyasal Katılım Üzerine Etkisi: SDÜ Örneği. Mehmet Akif Ersoy Üniversitesi Sosyal Bilimler Enstitüsü Dergisi, 7 (12): 196-219.

Fedayi, C. (2002). Siyaset Bilimi. İstanbul: Pınar Yayıncılık.

Fukuyama, F. (2000). Büyük Çözülme, İnsanın Doğası ve Toplumsal Düzenin Yeniden Oluşması. (Çev. Z. Avcl, A.T. Aydemir). İstanbul: Sabah Yayincllı.

George, D. and Mallery, M. (2010). SPSS for Windows Step by Step: A Simple Guide and Rference. Boston: Pearson.

Gökçe, Ali F., Özdemir, İ., ve İbrahim Halil C., (2016). Üniversite Öğrencilerin Siyasal Katılım Seviyesi: Kilis 7 Aralık Üniversitesi Örneği, Süleyman Demirel Üniversitesi Sosyal Bilimler Enstitüsü Dergisi, 27, 289-319.

Gökçimen, S. (2008). Ülkemizde Kadınların Siyasal Hayata Katılım Mücadelesi. Yasama Dergisi,10: 1-55.

Göksu, T. ve Bilgiç, V. (2003). Baskı Grupları ve Karar alma Mekanizmalarına Etkileri. Amme İdaresi Dergisi, 36(2): 51-66.

Görgülü, B. (2018). Gençlerin Siyasal Katılım Sürecinde Sosyal Medyanın Rolü, Yayınlanmamış Yüksek Lisans Tezi, Selçuk Üniversitesi Sosyal Bilimler Enstitüsü, Konya.

Gözler, K. (2004). Anayasa Hukukuna Giriş. (4.Basım), Bursa: Ekin Yayıncılık.

Gözler, K. (2014). Kısa Anayasa Hukuku. (10.Basım), Bursa: Ekin Yayıncllık.

Göztepe, E. (2016). Çoğunlukçu Demokrasi Anlayışına Karşı Çoğulcu Demokrasi Modelleri: Normatif Düzenleme Olanakları ve Bunun Sinırlilığı. http://www.google.com.tr/url?sa=t\&rct=j\&q=\&esrc=s\&source=web\&cd=1\&cad=rja\&uact=8\&ved $=2 \mathrm{ahUKEwjKnICW8YnbAhXEalAKHfU5AM8QFjAAegQIARAu \& url=http \% 3A \% 2F \% 2Fwww.k}$ amuhukukculari.org\%2Fupload\%2Fdosyalar\%2FCogunlukcu_Demorasi_Anlayisina_Karsi_Co gulcu_Demokrasi_Modelleri_1.pdf\&usg=AOvVaw0GhTc3QIDxGZX8e9CYw46q (Erişim Tarihi: 03.11.2018).

Gültekin, M. C. (2017). Üniversite Öğrencilerinin Siyasal Yaşama Katılım Boyutlarının İncelenmesi; Mardin Örneği, Hitit Üniversitesi Sosyal Bilimler Enstitüsü Dergisi, 10 (2), 1559-1580.

Heather, E. and Ulbig, K. (2012). Stacy, Social Butterflies and Politics: Exploring the Link Between Sociability and Political Engagement, Online and Off, Journal of Information Technology \& Politics, 9(4), 402-414.

İşlek, M. S. (2012). Sosyal Medyanın Tüketici Davranışlarına Etkileri: Türkiye'deki Sosyal Medyaların Üzerinde İnceleme, Yüksek Lisans Tezi, Karamanoğlu Mehmet Üniversitesi Sosyal Bilimler Enstitüsü, Karaman.

Kabaoğlu, İ. Ö. (2013). Özgürlük Hukuku. (7.Basım), İstanbul: İmge Yayıncılık. 
Kalaycıoğlu, E. (1986). Siyasal Katılmanın Kurallarına Genel Bir Bakış; Türkiye Örneği, Türk Siyasal Hayatın Gelişmesi Dergisi, İstanbul.

Kalaycıoğlu, E. (1983). Karşılaştırmalı Siyasal Katılma Siyasal Eylemin Ülkeler Üzerine Bir İncelenmesi, İstanbul Üniversitesi Siyasal Bilimler Dergisi, İstanbul.

Karagöz, K. (2010). Doğrudan Demokrasi Aracı Olarak Halk Girişimi. İstanbul: Vedat Yayıncılık.

Karaman, S., Yıldırım, S., ve Kaban, A. (2018). Öğrenme 2,0 yaygınlaşıyor: Web 2,0 uygulamalarına eğitimde kullanımına ilişkin araştırma ve sonuçları (Online) http://inettr.org.tr/inetconf13/kitap/karaman_yildirim_inet08.pdf (Erişim Tarihi: 10.09.2019).

Kartal, M. ve Bardakçı, S. (2019). Spss ve AMOS Uygulamalı Örneklerle Güvenirlik ve Geçerlik Analizleri. İstanbul: Ravza Yayıncılık.

Kapani, M. (2012). Politika Bilimine Giriş. (30.Basım), Ankara: Bilgi Yayıncılık.

Kaypak, Ş. (2010). Antakya'nın Kent Kimliği Açısından İrdelenmesi. Mustafa Kemal Üniversitesi Sosyal Bilimler Enstitüsü Dergisi, 7 (14): 373-392.

Kim and Kim, (2007). New and Old Media Uses and Political Engagement Among Korean Adolescents, Asian Journal of Communication, 17(4), 342-361.

Korkmaz, M. (2014). Sosyal Medya-Kamu Politikaları Etkileşimi Gezi Parkı Olayları Üzerine Bir Değerlendirme, Yüksek Lisans Tezi, Ankara Hacettepe Üniversitesi Sosyal Bilimler Enstitüsü, Ankara.

Kurt, N. (2001). Yarı Doğrudan Demokrasi Kurumlarının Yerel Yönetimler Düzeyinde Uygulanması. Yerel Yönetim ve Denetim Dergisi,6(2), 20-29.

Lewis M., (2010). A Hierarchical Regression Analysis of The Relationship Between Blog Reading, Online Political Activity and Voting During the Presidential Campaign, Dissertation Prepared for The Degree of Doctor of Philosophy.

Metin, O. (2010). Sosyal Medyanın Siyasal Toplumsallaşmaya Etkileri: Bir Alan Araştırması. Afyon Kocatepe Üniversitesi Sosyal Bilimler Dergisi, 18(2): 221-267.

Milbarth, L.W. (1965a). Political participation how and why no people get in volved in politics. Chicago: Rand McNally Collegep Oblishin Compeny. (Online)https://www.cambridge.org/core/journals/american-political-sciencereview/article/political-participation-how-and-why-do-people-get-involved-in-politics-bylester-w-milbrath-chicago-rand-mcnally-company-1965-pp-195175/112335F2C63425CDE62BE8B982926692 (Erişim Tarihi:23.10.2019).

Milbrath, L. W. (1965b). Political participation, Chicago, rand McNally and company. (Aktaran, Övünç, M.). Dijital Demokrasi: Türkiye'de Yeni Medya ve siyasal Katılım, Doktora Tezi, Maltepe Üniversitesi Sosyal Bilimler Enstitüsü, İstanbul.

Olsen, M. E. (1970). Social and Political Participation of Blacks. American Sociologicial Review. (Online) https://scholar.google.com/scholar_lookup?title=Social+and+Political+Participation+of+Blacks\& publication+year $=1970 \&$ author=Olsen+Marvin+E.\&journal=American+Sociological+Review\&vol ume $=35 \&$ doi=10.2307/2093944 (Erişim Tarihi:07.07.2019).

Öztekin, A. (2014). Siyaset Bilimine Giriş. (9.Basım), Ankara: Siyasal Yayıncılık. 
Özyurt, C. (2010). Üniversite Öğrencilerinin Siyasal Katılım Davranışları:29 Mart 2009 Yerel Seçimleri Balıkesir Örneği, Elektronik Sosyal Bilimler Dergisi, 9(33), 289-320.

Rice, L. L., Moffett, K. W, and Madupalli, R. (2012). Campaign related social networking and the political participation of college students. Social Science Computer Review. 313, 257-279.

Sağır, M. (2003). Küreselleşme Süreci ve Siyasal Katılımda Yeni Arayışları: Yerel gündem 21 Antalya Kent Konseyi Kadın Meclisi. Çă̆daş Yerel Yönetimler Dergisi, 11(4):28-41.

Skoric, M.M., and Nathaniel Poor, (2013). Youth Engagement in Singapur: The Interplay of social and traditional media. Journal of Broadcasting and Electronic Media, 57, 187-204.

Soysal, M. (1968). Halkın Yönetime Etkisi. Ankara: TODAİE Yayıncılık.

Şener, G., Emre, P. Ö. ve Akyıldız, F., (2015). Türkiye'de Sosyal Medyanın Siyasi Katılıma Etkileri, Folklorledebiyat Dergisi, 21(83), 75-98.

Temel, F., Önürmen, O. ve Köprü, M., (2014). Seçim Kampanyalarında Dijital Araçlar ve İnternetin Yeri: Üniversite Öğrencilerine Yönelik Bir Araştırma, Global Media Journal: TR Edition 5 (9), 320-337.

Tosun, L. P. (2018). Sosyal Ağlar ve Sosyal Psikoloji. Ankara: Nobel Yayıncılık.

Türkdoğan, O. (2000). Bilimsel Araştırma Metodolojisi. (3.Basım), İstanbul: TİMAŞ Yayıncılık.

Uyumaz, G., Dirlik E., ve Çokluk Ö. (2016). Açımlayıcı Faktör Analizinde Tekrar Edilebilirlik: Kavram ve Uygulama. Bolu Abant İzzet Baysal Üniversitesi Ĕ̆itim Fakültesi Dergisi,16 (2): 659-675.

Vaccari, C. (2013). Social Media and Political Communication a Survey of Twitter Users During the 2013 Italian General Election. Rivista Italiana di Scienza Politica. (Online) https://nyuscholars.nyu.edu/en/publications/social-media-and-political-communication-asurvey-of-twitter-user (Erişim Tarihi: 22.08.2019).

Velasquez, A. (2012). Social Media and Individual and Collective Activism: The Role of Interdependence and Online Political Efficacy. (Online) file://C:/Users/Ghost/Downloads/VelasquezPerilla_grad.msu_0128D_11355\%20(1).pdf (Erişim Tarihi: 15.05.2019).

Valenzuela, S., Park, N. K. and Kee, F. (2008). Lessons Form Facebook: The Effect of Social Network Sites on College Students, Social Capital, 9th International Symposuim on Online Journalism, Austin-Texas.

Velasquez A., (2016). Social media and individual and collective activism: the role of interdependence and online political efficacy, Doktora Tezi. ABD: Michigan State University, 2012, s.45 (Aktaran Kemal Elciyar), Sosyal Medyanın Üniversite Öğrencilerinin Siyasal Katılım Davranışlarına Etkisi, Yayınlanmamış Yüksek Lisans Tezi, Anadolu Üniversitesi Sosyal Bilimler Enstitüsü, Eskişehir.

Yıldız, M.M. (2014). Gençlik ve Siyasal Katılım: Diyarbakır Örneği, Yüksek Lisans Tezi, Dicle Üniversitesi Sosyal Bilimler Enstitüsü, Diyarbakır.

Yurdagül, H. (2016). Faktör analizinde KMO ve Bartlett testleri neyi Ölçer. (Online)http://yunus.hacettepe.edu.tr/ yurdugul/3/indir/Kuresellik.pdf (Erişim Tarihi: 17.06.2019). 
Wolton, D. (1991). Political Communication: The Construction of a Model, European Journal of Communication. (Online) https://journals.sagepub.com/doi/abs/10.1177/0267323190005001002 (Erişim Tarihi:12.06.2019). 